\title{
Cholangiocarcinoma in an American Rhea (Rhea Americana araneipes)
}

\section{Colangiocarcinoma em uma ema}

\author{
Paulo Ricardo Dell'Armelina Rocha ${ }^{\mathrm{I}}$ Letícya Lerner Lopes ${ }^{\mathrm{II}}$ Laura Peixoto de Arruda ${ }^{\mathrm{II}}$ \\ Caroline Argenta PescadorII Raquel Aparecida Sales da Cruz ${ }^{\text {III }}$ Edson Moleta Colodel ${ }^{\text {II }}$
}

\section{- NOTA -}

ABSTRACT

Cholangiocarcinomas are neoplasms that originate from the bile duct epithelium. The present case described a cholangiocarcinoma in an adult female American Rhea (Rhea Americana araneipes) by means of gross, histopathology and immunohistochemistry. Irregular, firm, multifocal, yellow-white masses, measuring from 0.4 to $6 \mathrm{~cm}$ in diameter were observed in both liver lobes. At the cut surface, multiple firm nodules filled with connective tissue were present. Microscopically, the neoplasia was composed of small, irregular, gland-like structures of neoplastic cells surrounded by connective tissue. The cells resembled epithelial cells of the hepatic biliary ducts. Neoplastic cells were positive for cytokeratin and negative for vimentin. This is the first report of a malignant fatal neoplasia in an American Rhea.

Key words: cholangiocarcinoma, Rhea, immunohistochemistry, wildlife.

\section{RESUMO}

Colangiocarcinomas são neoplasias originárias do epitélio do ducto biliar. O presente caso descreve os achados macroscópicos, microscópicos e imuno-histoquímicos de um colangiocarcinoma em uma ema fêmea (Rhea americana araneipes). No figado, massas irregulares, firmes, multifocais, de coloração amarelo-esbranquiçada, medindo de 0,4 a $6 \mathrm{~cm}$ de diâmetro foram observadas em ambos os lobos. Ao corte, múltiplos nódulos firmes preenchidos por tecido conjuntivo foram observados. Microscopicamente, a neoplasia era composta de células pequenas, irregulares, semelhantes às células do epitélio biliar, que formavam estruturas glandulares. A imuno-histoquímica foi positiva para citoqueratina e negativa para vimentina. Este trabalho constitui o primeiro relato de uma neoplasia maligna fatal em uma ema.

\author{
Palavras-chave: colangiocarcinoma, ema, imuno-histoquímica, \\ aves selvagens.
}

Cholangiocarcinomas are neoplasms that originate from the bile duct epithelium (ALBAHRANI et al, 2013). The neoplasm has an adenocarcinomatous pattern, producing ductules and acini, and sometimes papillary formations. Cells are cuboidal or columnar, with a small amount of slightly granular material (STALKER \& HAYES, 2007). Cholangiocarcinomas have been reported in dogs, cats, sheep, cattle, horses, and goats (CULLEN \& POPP, 2002). It has also been reported in many avian species, including a pheasant (OZMEN, 2012), a penguin (RENNER et al., 2001), a crane (ALLEN et al., 1985), an orange-winged Amazon parrot (COLEMAN, 1991), a blue-and-gold macaw (DEGERNES, 1998) and a peach-fronted conure (GIBBONS et al., 2002). Although cholangiocarcinoma is relatively uncommon in domestic animals, it is the most frequent hepatic neoplasm reported in captive and free-ranging birds (SCHMIDT et al., 2003). Greater Rheas (Rhea americana araneipes) are animals that are not threatened of extinction and are distributed through the South American continent (BIRDLIFE INTERNATIONAL, 2012). There are no reports of cholangiocarcinomas in terrestrial birds living in the tropics of South America. Moreover, there are no

\footnotetext{
'Departamento de Clínica, Cirurgia e Reprodução Animal, Universidade Estadual Paulista (UNESP), Av. Clovis Pestana, 793, Jd. Dona Amélia, 16050-680, Araçatuba, SP, Brasil. E-mail: ricardodellarmelina@gmail.com. Corresponding author.

IIDepartamento de Clínica Médica, Universidade Federal de Mato Grosso (UFMT), Cuiabá, MT, Brasil.

IIILaboratório de Patologia Veterinária, Universidade Federal do Rio Grande do Sul (UFRGS), Porto Alegre, RS, Brasil.
} 
reports of any kind of neoplasia in Greater Rheas, making it difficult for the zoo Veterinarian to make the correct diagnosis and establish a prognosis of diseases in this species. The present case described a cholangiocarcinoma in an American Rhea by means of gross, histopathology and immunohistochemistry.

A female American Rhea was found dead at the Zoo of the Federal University of Mato Grosso (UFMT), Cuiabá, Mato Grosso, Brazil. The animal was referred to the Laboratory of Veterinary Pathology at the Veterinary Hospital of UFMT for a complete necropsy. Fresh samples of the neoplasia, brain, spinal cord, proventriculus, gizzard, duodenum, liver, lungs, kidneys and heart were fixed in $10 \%$ buffered formaldehyde solution. Subsequently, the tissues were routinely processed, embedded in paraffin and $4 \mu \mathrm{m}$ tissue sections were cut for histopathologic and immunohistochemical (IHC) evaluations. The sections for histopathology were stained with hematoxylin and eosin (H\&E). Grossly, irregular, firm, multifocal, yellow-white masses, measuring from 0.4 to $6 \mathrm{~cm}$ in diameter were observed in both liver lobes. The masses were compressing the adjacent liver parenchyma (Figure 1A and B). At the cut surface, multiple firm nodules filled with connective tissue were present. No significant macroscopic findings were observed in other organs. Microscopically, the mass was composed of small, irregular, glandlike structures of neoplastic cells surrounded by connective tissue. The cells resembled epithelial cells of the hepatic biliary ducts, were round to polygonal, with and hypertrophic vacuolyzed nucleus and a frequently visible and lateralized nucleolus (Figure 1C). Cytoplasm was normally visible. Cellular polymorphism and neovascularization were moderately observed; 1-2 mitoses per 400x field were observed; necrosis of neoplastic cells and vascular invasion were not present. Multifocal mild infiltration of lymphocytes and heterophils in the neoplasm was also observed. In the areas adjacent to the liver

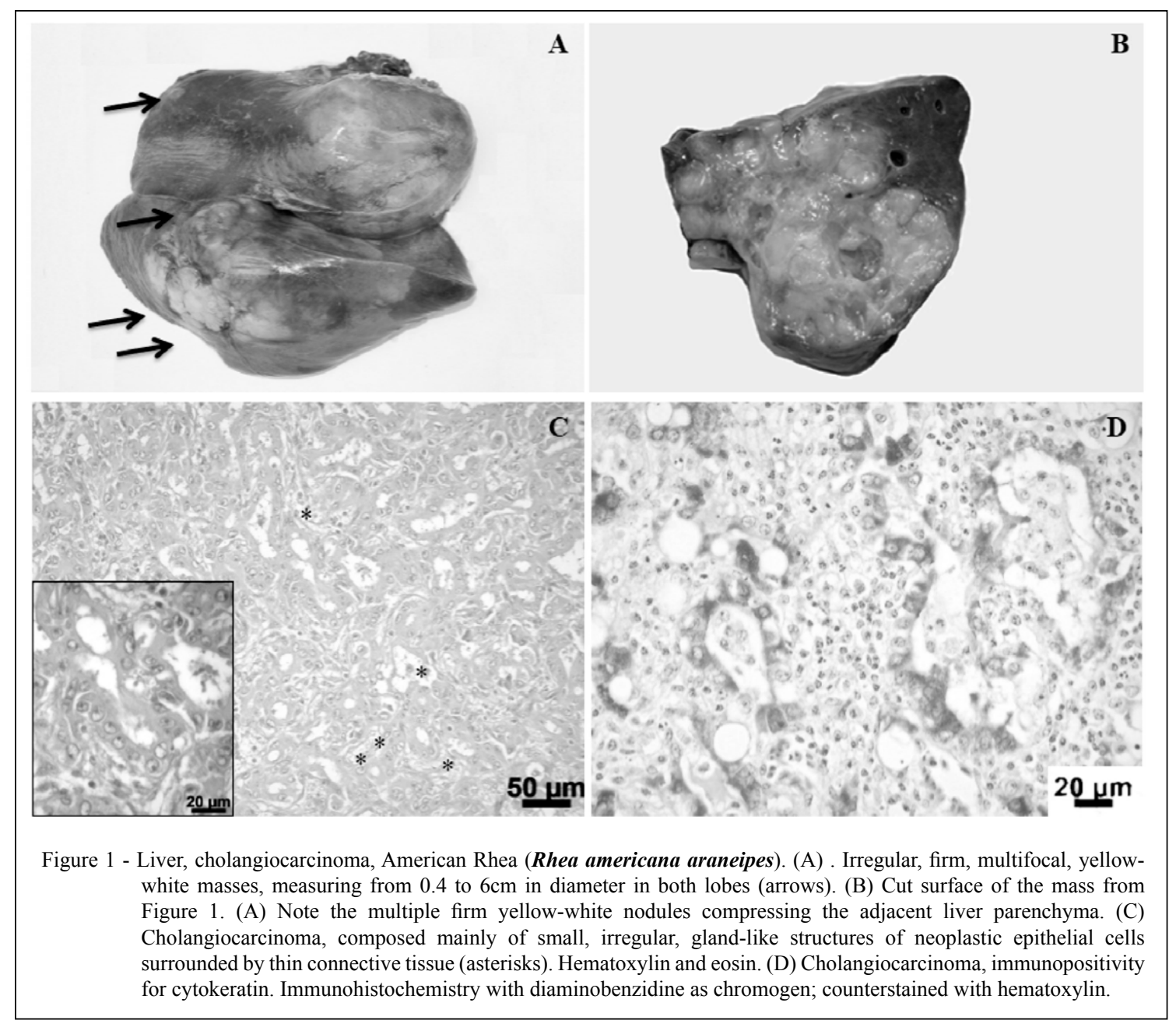

Ciência Rural, v.45, n.2, fev, 2015. 
parenchyma, hepatocytes were degenerated and a marked proliferation of fibroblasts was also observed.

Briefly, indirect immunohistochemistry was performed using monoclonal primary antibodies (RAMOS-VARA et al., 2008) against cytokeratin (DAKO, Carpinteria, USA, Code M3515, 1:200) and vimentin (DAKO, Code M7020, 1:100). For antigen retrieval, all sections were incubated with citrate buffer $(\mathrm{pH} 6.0)$ at $125^{\circ} \mathrm{C}$ for $10 \mathrm{~min}$. The secondary kit detection system LSAB2-HRP kit (Code K0679, DAKO, USA), biotin labelled goat anti-rabbit + goat anti-mouse was applied. Subsequently, permanent red was incubated for 30 minutes at room temperature (only for vimentin) and 3,3'-diaminobenzidine chromogen (DAB, DAKO, USA, cytokerin) was incubated for $1 \mathrm{~min}$ at room temperature. Finally, the sections were counterstained using Mayer's hematoxylin. Positive controls included a mammary carcinoma from a dog and a normal liver from a chicken. Sections of the neoplasia herein described and the positive controls without the incubation of the primary antibody were used as negative controls. Neoplastic cells were positive for pancytocheratin (Figure 1D). Vimentin was negative in the neoplastic cells.

According to CULLEN \& POPP (2002) and based on the results, the present case was diagnosed as a cholangiocarcinoma. In domestic animals, cholangiocarcinomas have a highly invasive pattern of growth and metastasize frequently, mostly within the liver; however, it is not possible to distinguish multiple primary sites of origin from metastasis (CULLEN \& POPP, 2002). Cholangiocarcinomas are most frequently multinodular; hematogenous metastases are unusual, but metastases to regional lymph nodes are common and mitosis are frequently observed (CULLEN \& POPP, 2002). In the present case, although few mitoses were observed, no metastasis was present. These results might be related to an early stage of development of the neoplasm or possibly due to an exposure to low doses of carcinogen agent/stimuli. Although there is no specific predisposing factor for cholangiocarcinomas in animals (ANDRADE et al., 2012, CULLEN \& POPP, 2002), chronic exposion to aflatoxins (produced by Aspergillus fungi in a humid environment) from seeds (BATATINHA et al., 2008) might be a cause of the cholangiocarcinoma in this bird. Moreover, inflammation of the biliary epithelium as a result of parasitic infections, mostly by flukes - such as Clonorchis sinensis and Platynosomum fastosum - has been associated with biliary carcinoma and cholangiocarcinoma in dogs and cats, respectively (ANDRADE et al., 2012, CULLEN \& POPP,
2002). Nevertheless, the mechanism by which the parasite promotes the tumor development is unknown (CULLEN \& POPP, 2002). Furthermore, in humans of East Asia, liver flukes (Opisthorchis viverrini and Clonorchis sinensis) are considered carcinogenic to humans by the International Agency for Cancer Research, and these parasites are responsible for the high rates of cholangiocarcinomas in these regions (RALPHS \& KHAN, 2013). Additionally, exposure to chemical compounds, such as naphthenic acids, primary sclerosing cholangitis, anabolic steroids, ulcerative colitis, intrahepatic lithiasis, Caroli disease and multiple liver cysts are other recognized predisposing factors for the development of cholangiocarcinomas in humans (AL-BAHRANI et al., 2013). Histologically, cholangiocarcinomas must be distinguished from hepatocellular carcinomas, hepatic carcinoids and cholangiomas (CULLEN \& POPP, 2002). Distinction from hepatocellular carcinoma of adenoid pattern may be assisted by demonstration of mucin, abundant mitotic figures, and presence of a prominent connective tissue stroma (STALKER \& HAYES, 2007). In conclusion, this is the first report of a malignant fatal neoplasia in an American Rhea.

\section{ACKNOWLEDGEMENTS}

To Conselho Nacional de Desenvolvimento Científico e Tecnológico (CNPq) and Fundação de Amparo à Pesquisa do Estado de São Paulo (FAPESP). Grant number 2013/08702-4 for finantial suport.

\section{REFERENCES}

AL-BAHRANI, R. et al.v Cholangiocarcinoma: risk factors, environmental influences and oncogenesis. Annals of Clinical \& Laboratory Science, v.43, p.195-210, 2013. Available from: <http:// www.ncbi.nlm.nih.gov/pubmed/23694797>. Accessed: May 04, 2013.

ALLEN, J.L. et al. Metastatic cholangiocarcinoma in a Florida sandhill crane. Journal of the American Veterinary Medical Association, v.187, p.1215, 1985. Available from: <http://www. ncbi.nlm.nih.gov/pubmed/3001002>. Accessed: May 04, 2013.

ANDRADE, R.L. et al. Platynosomum fastosum-induced cholangiocarcinomas in cats. Veterinary Parasitology, v.23, p.277-280, 2012. Available from: <http://www.ncbi.nlm.nih.gov/ pubmed/22963714>. Accessed: May 04, 2013.

BATATINHA, M.J.M. et al. Micotoxicoses. In: SPINOSA, H.S; GÓRNIAK, S. L.; PALERMO-NETO, J. Toxicologia aplicada à Medicina Veterinária. São Paulo: Manole, 2008. p.482-491.

BIRDLIFE INTERNATIONAL 2012. Rhea americana. In: IUCN 2013. IUCN Red List of Threatened Species. Version 2013.2. Accessed: Apr. 04, 2014. Online. Available from: <http://www. iucnredlist.org/details/22678073/0>. 
COLEMAN, C.W. Bile duct carcinoma and cloacal prolapse in an orange-winged Amazon parrot (Amazona amazonica amazonica). Journal of Avian Medicine and Surgery, v.5, p.87-89, 1991.

CULLEN, J.M.; POPP, J.A. Tumors of the liver and gall bladder. In: MEUTEN, D.J. Tumors in domestic animals. 4.ed. Ames: Iowa State, 2002. p.483-508.

DEGERNES, L.A. et al. Multicystic biliary adenocarcinoma in a blue-and-gold macaw (Ara ararauna). Journal of Avian Medicine and Surgery, v.12, p.100-107, 1998.

GIBBONS, P.M. et al. I nternal papillomatosis with intrahepatic cholangiocarcinoma and gastrointestinal adenocarcinoma in a peach-fronted conure (Aratinga aurea). Avian Diseases, v.46, p.1062-1069, 2002. Available from: <http://www.ncbi.nlm.nih. gov/pubmed/12495076>. Accessed: May 04, 2013.

OZMEN, O. Cholangiocarcinoma in a ring-necked pheasant (Phasianus colchicus): a case report. Veterinarni Medicina, v.57, p.320-323, 2012.
RALPHS, S.; KHAN, S.A. The role of the hepatitis viruses in cholangiocarcinoma. Journal of Viral Hepatitis, v.20, p.297305, 2013. Available from: <http://www.ncbi.nlm.nih.gov/ pubmed/23565610>. Accessed: May 04, 2013.

RENNER, M.S. et al. Cholangiocarcinoma with metastasis in a captive Adelie penguin (Pygoscelis adeliae). Journal of Zoo and Wildlife Medicine, v.32, p.384-6, 2001. Available from: $<$ http://www.ncbi.nlm. nih.gov/pubmed/12785690>. Accessed: May 04, 2013.

SCHMIDT, R.E et al. Pathology of pet and aviary birds. Ames: Blackwell Publishing, 2003. p.88-89.

RAMOS-VARA, J.A. et. al. Suggested guidelines for immunohistochemical techniques in veterinary diagnostic laboratories. Journal of Veterinary Diagnostic Investigation, v.20, n.4, p.393-413, 2008. Available from: <http://www.ncbi.nlm. nih.gov/pubmed/18599844>. Accessed: May 04, 2014.

STALKER, M.J.; HAYES, M.A. Liver and biliary system. In: MAXIE, M.G. Pathology of domestic animals, Jubb, Kennedy and Palmer's. 5.ed. New York: Elsevier, 2007. p.385. 